\title{
GAMBARAN SUBJECTIVE WELL-BEING PADA ANAK YANG MEMILIKI ORANG TUA PENYANDANG TUNANETRA SEJAK LAHIR
}

\author{
Invokavit Putri Mbarasi Wau', Rudangta Arianti² \\ 1,2Program Studi Psikologi Universitas Kristen Satya Wacana, email: invokavitputriwau@gmail.com
}

\section{ABSTRACT: DESCRIPTION OF SUBJECTIVE WELL-BEING IN CHILDREN WHOSE PARENTS WERE BLIND SINCE BIRTH}

The purpose of this study was to determine the description of subjective well-being in children whose parents were blind since birth. This study uses a case study qualitative approach. The selection of research subjects using snowball. Characteristics of the subjects aged 13 to 18 , unmarried, and has parents who are blind since birth. The data collection method uses in-depth interview techniques. The results showed that subjective well-being in children whose parents were blind, includes cognitive evaluation that is life satisfaction and affective evaluation. Subjective well-being aspects on the subject of life satisfaction are influenced by the domain of family, friends, school, job, and future. Their positive affects are happy, proud, and affection. Negative affects that appear are sad and depressed feeling. For further research, it is expected to discuss and compare subjective well-being with other persons with disabilities.

\section{Keywords: Subjective Well-Being, Blind Individuals}

Tujuan penelitian ini adalah untuk mengetahui gambaran subjective well-being pada anak yang memiliki orang tua penyandang tunanetra sejak lahir. Penelitian ini menggunakan pendekatan kualitatif studi kasus. Pemilihan subyek penelitian menggunakan snowball. Karakteristik subyek adalah yang berusia 13 sampai 18 tahun, belum menikah dan memiliki orang tua penyandang tunanetra sejak lahir. Metode pengumpulan data menggunakan teknik wawancara mendalam. Hasil penelitian menunjukkan subjective well-being pada anak yang memiliki orang tua penyandang tunanetra, meliputi penilaian kognitif yaitu kepuasan hidup dan penilaian afektif. Aspek subjective well-being pada subyek yaitu kepuasaan hidup yang dipengaruhi oleh domain keluarga, teman, sekolah, pekerjaan, dan masa depan. Afek positif yang mereka alami yaitu senang, bangga, dan kasih sayang. Afek negatif yang muncul adalah sedih dan perasaan tertekan. Untuk penelitian selanjutnya diharapkan dapat membahas dan membandingkan subjective wellbeing dengan penyandang disabilitas lainya.

\section{Kata Kunci: Subjective Well-Being, Tunanetra}

\section{PENDAHULUAN}

Jumlah penyandang disabilitas terus mengalami peningkatan setiap tahunnya. Terdapat 15 dari 100 orang yang menyandang disabilitas di dunia di antaranya yaitu 2 hingga 4 dari 100 orang mengalami disabilitas berat (WHO, 2011). Berdasarkan Survei Penduduk Antar Sensus menunjukkan jumlah penyandang disabilitas di Indonesia sebanyak 21,5 juta jiwa dengan kesulitan mengingat atau berkonsentrasi, kesulitan berjalan maupun naik tangga, kesulitan menggunakan dan menggerakkan tangan atau jari, kesulitan melihat, kesulitan mendengar, gangguan perilaku dan atau emosional, gangguan berbicara dan memahami atau berkomunikasi dengan orang lain, dan kesulitan mengurus diri sendiri (Kemenkes, 2018). Melihat fakta jumlah penyandang disabilitas memungkinkan sebagian kecil keluarga memiliki kerabat yang menyandang disabilitas, tidak menutup kemungkinan seorang penyandang 


\section{GAMBARAN SUBJECTIVE WELL BEING PADA ANAK YANG MEMILIKI ORANG TUA PENYANDANG TUNA NETRA SEJAK LAHIR}

disabilitas membangun kehidupan berkeluarga dan mempunyai anak (Rusch, 2003).

Sejarah telah memperlihatkan bahwa setiap orang dengan penampilan atau tubuhnya berbeda akan dianggap masyarakat sebagai normatif, normalitas, dan sesuatu yang tidak diinginkan bahkan tidak dapat diterima sebagai bagian dari komunitas tertentu (Rothman, 2018). Penyandang disabilitas cenderung diabaikan karena dianggap sebagai warga masyarakat yang tidak produktif maupun tidak dapat melakukan tugas dan tanggung jawab dengan baik (Kasim, dkk., 2010). Penyandang tunanetra adalah individu dengan ketidakmampuan melihat, keterbatasan fisik dalam melihat membuat mereka terkendala dalam melakukan aktifitas sehari-hari. Masyarakat sering menganggap remeh dan disisihkan oleh masyarakat (Schinazi, 2007).

Hal ini tidak hanya berdampak bagi penyandang disabilitas fisik seperti penyandang tunanetra, tetapi mampu memengaruhi keluarga lainnya yang tidak menyandang disabilitas. Survei penelitian terdahulu oleh Sari \& Coralia (2015) menemukan istri yang memiliki suami penyandang tunanetra sering merasa dirinya direndahkan, kecewa, merasa kurang dukungan dari lingkungan sekitar, sedih dan kurang percaya diri. Mereka juga menerima perlakuan yang tidak menyenangkan dari pihak keluarga yang belum bisa menerima suaminya bahkan ada yang mengucilkan suami. Perlakukan tidak menyenangkan juga dialami oleh anak dalam lingkungan sosialnya seperti teman-teman sebayanya mengejek kondisi fisik tunanetra pada ayahnya.

Anak, berjalannya waktu akan membangun relasi dengan orang-orang yang memiliki karakteristik pandangan akan orang tua penyandang tunanetra, memandang sebagai sesuatu hal yang biasa dan ada pula yang memandang sebagai sesuatu yang aneh. Pada usia remaja dimulai 13-18 tahun seorang anak akan terus melakukan penyesuaian diri terhadap kelompok sebaya, mendambakan identitas diri, memiliki masalah-masalah identitas-ego, semakin gelisah untuk meninggalkan stereotip (Hurlock, 1997). Apabila nilai yang dikembangkan yaitu sesuatu yang tidak menyenangkan ataupun saling mengejek maka menimbulkan bahaya bagi perkembangan jiwa individu begitupun sebaliknya. Pada penelitian terdahulu oleh Coralia menemukan bahwa anak memperoleh perlakukan yang tidak menyenangkan dari lingkungan sosial terutama dari teman-teman sebayanya, seperti mengejek fisik tunanetra pada ayahnya. Anak akan merasakan kesedihan, perasaan tertekan, bahkan menarik diri dari lingkungan sebaya, hal ini merupakan indikator bahwa anak memiliki subjective well-being yang rendah dalam lingkungan sosial. Subjective well-being yang rendah juga dapat dilihat dari lingkup keluarga apabila keterbatasan fisik membuat fungsi ayah atau ibu mulai bergeser, maka dapat membuat anak merasa kurang dihargai, diperhatikan, sulit

Invokavit Putri Mbarasi Wau, Program Studi Psikologi Universitas Kristen Satya Wacana. Email: ivnvokavitputriwau@gmail.com

Rudangta Arianti, Program Studi Psikologi Universitas Kristen Satya Wacana. Email: rudangta.sembiring@uksw.edu 


\section{GAMBARAN SUBJECTIVE WELL BEING PADA ANAK YANG MEMILIKI ORANG TUA PENYANDANG TUNA NETRA SEJAK LAHIR}

berkomunikasi, merasa malu berada di lingkungan sosialnya.

Subjective well-being merupakan kebahagiaan yang diperoleh dari hasil evaluasi kognitif dan afektif pada seluruh ranah kehidupan (Diener, 2009). Evaluasi meliputi penilaian emosional terhadap berbagai kejadian yang dialami yang sejalan dengan penilaian kognitif terhadap kepuasan dan pemenuhan kebutuhan (Diener, dkk., 2002). Kepuasan hidup adalah penilaian kognitif pada standar kehidupan yang telah ditetapkan oleh individu (Pavot \& Diener, 1993). Kepuasan hidup meliputi berbagai domain kehidupan seperti pekerjaan, hubungan, waktu luang, perkawinan (Diener, dkk., 2003). Indikator kepuasan hidup yaitu menerima kehidupan sekarang, menerima kehidupan masa lalu, keinginan untuk mengubah hidup, menerima masa depan, dan memiliki pemikiran atas pandangan orang dekat (Diener dkk., 1999). Komponen afektif positif muncul dalam bentuk emosi menyenangkan seperti bahagia, bangga, kasih sayang, senang dan penuh gairah (Diener \& Suh, 1997). Sementara, afektif negatif termasuk suasana hati yang tidak menyenangkan seperti perasaan sedih, merasa bersalah, memiliki penyesalan, kemarahan, perasaan tertekan, kecemasan dan perasaan iri (Diener dkk., 1999).

Rees, dkk. (2010) menyebutkan 10 ranah penting SWB pada anak pada penelitian di Inggris mengenai kesejahteraan anak, yaitu keluarga, teman-teman, kesehatan, penampilan, penggunaan waktu luang, masa depan, rumah, uang dan kepemilikan, sekolah, dan pilihan dalam hidup. Menurut Strózik, dkk., (2016), domain SWB anak adalah keluarga, sekolah, teman, lingkungan tempat tinggal, dan diri sendiri. Subjective well-being tinggi pada anak ditandai dengan mampu menyesuaikan diri dalam lingkungan (Amato, 2005; Lam, dkk., 2012), dapat meningkatkan kondisi kesehatan mental individu (Meggiolaro \& Ongaro, 2014) serta memiliki keinginan berbakti pada orang tua dengan keluarga berlatar belakang budaya kolektif (Chen, 2014). Subjective well-being rendah ditandai dengan sikap yang tidak berdamai dan memandang suatu peristiwa tidak menyenangkan untuk dilakukan. Suldo dan Fefer (2013) juga mengungkapkan bahwa tingkat subjective well-being rendah pada anak ditandai dengan tingginya resiko putus sekolah, kurang memiliki empati, kegagalan dalam menjalin relasi antar individu, keterlibatan pada kriminalitas, penyalahgunaan alkohol dan obat-obatan terlarang.

Terdapat dua faktor pengaruh wellbeing pada keluarga dari sisi anak dan orang tua, yaitu faktor tidak langsung dan faktor langsung. Faktor tidak langsung yaitu dukungan dari orang tua, relasi dengan kakek-nenek, pengaruh terhadap kelas sosial, pendidikan, kepuasan kerja serta umur. Sedangkan faktor langsung yaitu proses keberfungsian dalam keluarga, kepribadian, dan lingkungan sosial-ekonomi keluarga (McKeown, Pratschke \& Haase, 2003).

Invokavit Putri Mbarasi Wau, Program Studi Psikologi Universitas Kristen Satya Wacana. Email: ivnvokavitputriwau@gmail.com

Rudangta Arianti, Program Studi Psikologi Universitas Kristen Satya Wacana. Email: rudangta.sembiring@uksw.edu 


\section{GAMBARAN SUBJECTIVE WELL BEING PADA ANAK YANG MEMILIKI ORANG TUA PENYANDANG TUNA NETRA SEJAK LAHIR}

Penelitian terdahulu Subjective Well-Being Pada Istri yang Memiliki Pasangan Tunanetra oleh Sari \& Coralia (2015) menemukan Istri dari suami tunanetra yang memiliki tingkat subjective wellbeing tinggi menilai bahwa kehidupannya memuaskan dan membahagiakan, tidak ada kesenjangan antara standar pribadinya dengan apa yang sudah ia capai dalam pernikahannya sehingga mereka mudah bereaksi dengan emosi yang menyenangkan sebab merasa bahwa banyak hal baik yang terjadi dalam hidupnya. Berdasarkan latar belakang tersebut, peneliti ingin mengetahui gambaran subjective wellbeing dari sisi anak yang memiliki orang tua penyandang tunanetra sejak lahir dan faktorfaktor yang memengaruhinya.

\section{METODE}

Metode yang digunakan dalam penelitian ini menggunakan penelitian kualitatif dengan jenis pendekatan studi kasus. Pengambilan sampel menggunakan teknik snowball sampling. Partisipan pada penelitian ini adalah anak, dengan kriteria: 1) anak berusia 1318 tahun, 2) belum menikah, 3) anak yang memiliki ayah atau ibu dengan penyandang tunanetra sejak lahir. Lokasi penelitian ini dilakukan di kota Batam dan sekitarnya. Profil partisipan dapat dilihat pada tabel 1:
Tabel 1

Profil Partisipan.

\begin{tabular}{lll}
\hline \multicolumn{1}{c}{ Faktor } & \multicolumn{1}{c}{$\begin{array}{c}\text { Partisipan 1 } \\
(\mathrm{P} 1)\end{array}$} & \multicolumn{1}{c}{$\begin{array}{c}\text { Partisipan 2 } \\
(\mathrm{P} 2)\end{array}$} \\
\hline Usia & 16 & 17 \\
\hline Jenis Kelamin & Laki-laki & Laki-laki \\
\hline Pekerjaan & Pelajar & Security \\
\hline Pendidikan & SMP & SD \\
Terakhir & &
\end{tabular}

Dalam penggalian data menggunakan teknik wawancara dengan instrumen berupa pedoman umum wawancara yang dibuat oleh peneliti mengacu pada indikator komponen subjective well-being yaitu kepuasan hidup (pada domain kehidupan keluarga, teman, kesehatan, penggunaan waktu luang, masa depan, sekolah), komponen afektif positif (bahagia, bangga, kasih sayang, senang dan penuh gairah) dan afektif negatif (perasaan sedih, merasa bersalah, memiliki penyesalan, kemarahan, perasaan tertekan, kecemasan dan perasaan iri). Teknik wawancara yang digunakan oleh peneliti yaitu wawancara mendalam. Wawancara dilakukan melalui panggilan telepon akibat adanya pandemi Covid-19. Wawancara ini dilakukan pada bulan Maret hingga bulan Mei 2021. Pada P1 dilakukan pertama kali pada 04 Maret 2021, dilanjutkan pada 08 April 2021 dan 09 Mei 2021. Pada P2 dilakukan pada 4 Maret 2021 dan selanjutnya melalui via chat pada aplikasi WhatsApp. Pada saat wawancara menggunakan

Invokavit Putri Mbarasi Wau, Program Studi Psikologi Universitas Kristen Satya Wacana. Email: ivnvokavitputriwau@gmail.com

Rudangta Arianti, Program Studi Psikologi Universitas Kristen Satya Wacana. Email: rudangta.sembiring@uksw.edu 


\section{GAMBARAN SUBJECTIVE WELL BEING PADA ANAK YANG MEMILIKI ORANG TUA PENYANDANG} TUNA NETRA SEJAK LAHIR

alat perekam, data hasil wawancara kemudian dianalisis.

Analisis data dilakukan melalui beberapa tahap yaitu mengolah dan mempersiapkan data untuk dianalisis yaitu membuat verbatim wawancara, membaca keseluruhan data yang diperoleh di lapangan, melakukan coding kemudian menggunakan hasil coding untuk menemukan setting (ranah), partisipan, kategori dan tema yang akan dianalisis, kemudian menarasikan hasil penelitian, melakukan interpretasi hasil penelitian (Creswell, 2016). Peneliti juga melakukan triangulasi data dan menerapkan member checking. Triangulasi data dilakukan peneliti dengan melalukan member checking dengan membawa hasil penelitian kepada subjek penelitian untuk mengecek kebenaran deskripsi yang dibuat peneliti (Creswell, 2014).

\section{HASIL}

Pada penelitian ini terdapat dua partisipan utama yaitu anak yang memiliki orang tua penyandang tunanetra. Partisipan 1 (P1) adalah seorang pelajar kelas 1 SMK jurusan arsitek. $\mathrm{P} 1$ berjenis kelamin laki-laki yang berusia 16 tahun. P1 merupakan anak pertama dari tiga bersaudara, adik $\mathrm{P} 1$ berjenis perempuan berusia sepuluh tahun dan enam tahun yang tinggal dan dibesarkan oleh kedua orang tua hingga saat ini.

Partisipan 2 (P2) adalah seorang pekerja yang bekerja sebagai security di komplek rumah, sesekali juga mengambil pekerjaan sampingan di bengkel. $\mathrm{P} 2$ berumur 17 tahun dan sudah tidak melanjutkan sekolah lagi, P2 sudah putus sekolah sejak kelas 2 SMP. Saat ini P2 hanya fokus untuk mencari pengalaman dalam bekerja dan terus bekerja. P2 tinggal bersama ayah, ibu dan seorang adik perempuannya. P2 merupakan anak pertama dari dua bersaudara, adik P2 berjenis kelamin perempuan berusia empat tahun.

\section{Kepuasan Hidup}

P1 merasa puas terhadap hidupnya saat ini, dia bersyukur masih memiliki orang tua yang masih memperhatikan, masih menegur, dan menafkahi kebutuhan $\mathrm{P} 1$ yang masih belum dapat menghasilkan penghasilan sendiri. Memiliki ayah penyandang tunanetra bukanlah penghambat untuk P1 terus melanjutkan hidup, justru dengan keterbatasan ayah P1 merasa kagum karena tetap dapat melakukan hal seperti orang normal lainnya dan bisa bekerja untuk memenuhi kebutuhan keluarga.

P2 juga merasa puas terhadap hidupnya saat ini, karena tidak ada sesuatu yang perlu dikhawatirkan dan mengatakan hidup harus dinikamatin. Memiliki kondisi kesehatan yang baik dan memiliki pekerjaan yang baik juga merupakan kepuasan P2. P2 yang saat ini sudah memilih untuk bekerja juga merasa puas karena tidak mebebankan keluarga lagi dalam hal kebutuhan pribadi P2 sendiri, bahkan dia merasa ingin terus dapat membelikan sesuatu yang diinginkan oleh orang tua.

Invokavit Putri Mbarasi Wau, Program Studi Psikologi Universitas Kristen Satya Wacana. Email: ivnvokavitputriwau@gmail.com

Rudangta Arianti, Program Studi Psikologi Universitas Kristen Satya Wacana. Email: rudangta.sembiring@uksw.edu 


\section{GAMBARAN SUBJECTIVE WELL BEING PADA ANAK YANG MEMILIKI ORANG TUA PENYANDANG TUNA NETRA SEJAK LAHIR}

"Yaa semua bisa selalu sehat

waalfiat, kerjaannya baik terus

kak, soalnya kan saya kalau

apa kan saya dibilang belikan

dulu lah ini biar saya bisa

belikan apapun itu." -P2

Kepuasan pada anak yang memiliki orang tua penyandang tunanetra ini bisa dirinci berdasarkan domain kehidupan yang meliputi keluarga, teman, sekolah, pekerjaan, masa depan. Pada domain keluarga, P1 merasa berkecukupan walaupun ayah memiliki keterbatasan fisik namun ayah P1 masih bisa bekerja sebagai penggiling beras untuk menafkahi kebutuhan keluarga. P1 juga mengatakan dengan keadaan ekonomi yang pas-pasan namun keluarga P1 masih dapat berbagi dengan tetangga yang lebih membutuhkan jika sedang mendapatkan rejeki maupun ada acara keagamaan

"Kadang kalau ada rejeki ya bagi-bagi buat orang-orang apalagi di pandemik gini dan apa ya kadang suka kasih event misal kek ada paskah bagi-bagi sesuatu dilingkungan sekitar." -P1

P1 juga merasa bersyukur karena masih memiliki waktu-waktu bersama keluarga, dapat menjalankan ibadah bersama dan makan bersama. Walaupun hal tersebut tidak terjadi setiap hari namun P1 merasa senang.
"Ya biasa doa pagi atau nggak pas hari jumat itu bisa kumpulkumpul bareng pas ibadah, kadang juga sempatin makan bareng, tapi kalau makan bareng gitu paling cuma seminggu dua kali, tiga kali, sekali, nggak setiap kali cuman gitu aja ya gapapa tetap senang" -P1

Berbeda dengan P2, P2 tidak memiliki waktu bersama keluarga karena pekerjaan, ayah P2 bekerja sebagai pijat urut disebuah klinik pijat urut tunanetra dengan jam bekerja pukul 10.0021.00 WIB, sedangkan P2 bekerja sebagai security dengan jam kerja pukul 24.00-05.00 WIB. Ketika pulang kerja P2 langsung istirahat sehingga waktu di pagi hari yang harusnya bisa berkumpul bersama keluarga tidak ada, lalu ketika siang hingga malam hari P2 akan ke bengkel teman jika ada pekerjaan atau mencari pekerjaan sampingan yang dapat dilakukan, jika ada waktu kosong P2 akan bermain dengan teman-temannya.

Kondisi ekonomi keluarga P2 dapat dikatakan berkecukupan walaupun P2 harus bekerja juga setidaknya untuk memenuhi kehidupan pribadi. Hubungan dengan ayah tidak begitu akrab karena faktor jarang bertemu atau berkumpul bersama, sedangkan dengan ibu cukup memiliki hubungan yang akrab karena ibu selalu di rumah sehingga sering memiliki waktu untuk berbicara maupun bercanda. Namun,

Invokavit Putri Mbarasi Wau, Program Studi Psikologi Universitas Kristen Satya Wacana. Email: ivnvokavitputriwau@gmail.com

Rudangta Arianti, Program Studi Psikologi Universitas Kristen Satya Wacana. Email: rudangta.sembiring@uksw.edu 


\section{GAMBARAN SUBJECTIVE WELL BEING PADA ANAK YANG MEMILIKI ORANG TUA PENYANDANG TUNA NETRA SEJAK LAHIR}

sebelum almarhum nenek P2, P2 lebih memiliki hubungan yang sangat akrab dengan nenek dikarenakan sebelum nenek almarhum, kedua orang tua P2 bekerja sehingga tidak sering bertemu, P2 rela tidak tinggal bersama keluarga asal bersama nenek yang rumahnya tidak jauh dari rumah $\mathrm{P} 2$

Dengan kondisi memiliki ayah tunanetra, kedua partisipan tidak merasa dikucilkan dan tidak pernah diejek oleh temanteman sebayanya, justru teman-teman kedua partisipan merasa kagum kepada kedua ayah partisipan karena memiliki talenta seperti bisa bermain musik dan mengerti mesin pengiling beras. P1 memiliki hubungan yang baik dengan teman-temannya, P1 merasa beryukur memiliki teman yang mendukung dan menyemangati ketika memiliki masalah dalam pendidikannya. P1 sangat dekat dengan teman-teman satu grup musiknya dikarenakan memiliki hobi yang sama, dengan teman sekolahnya P1 tidak begitu akrab karena jarang bertemu semenjak sekolah daring hingga saat ini.

"Yaa kalau pas gimana ya,
capek ehh habis ngerjain
tugas terus nggak semangat
ngapa-ngapain, trus nanti
paling teman ajak kemana
terus ngopi bareng gituajakak
biar nggak pusing di rumah
katanya"-P1

P2 juga memiliki teman, namun ketika masih dibangku sekolah teman yang dimiliki membawa dampak buruk bagi pendidikannya. P2 ikut terjerumus dalam pergaulan buruk seperti sering bolos sekolah, terlambat berangkat sekolah maupun sering merokok dengan temantemannya, sehingga hal ini membuat P2 dikeluarkan dari sekolah.

“...sebab kita selalu kabur, tempat nongkrong saya pun di sini juga, apalagi dulu kalau mau berangkat sekolah ngumpul di sini dulu, di sini itu bukan nongkrong-nongkrong aja tapi merokok dulu baru berangkat sekolah." -P2

Namun, walaupun begitu hubungan dengan teman-temannya masih akrab hingga saat ini. Ketika dulu P2 pernah kabur dari rumah karena dikeluarkan dari sekolah, P2 sempat tinggal selama seminggu di rumah teman. Saat sekarang memilih untuk bekerja, P2 tidak jarang memiliki tawaran bekerja dari teman-temannya yang memiliki info pekerjaan dan masih sering berkumpul atau nongkrong.

Dalam hal pendidikan, P1 merasa kurang puas karena saat memasuki SMK P1 harus melalui pembelajaran daring, hal ini membuat P1 kurang semangat belajar dan tidak mengerti pembelajarannya karena tidak ada penjelasan guru, hanya sistem kirim materi dan tugas melalui google classsroom. Akibatnya, P1 sering tidak mengerjakan tugas sekolah karena tidak mengerti materi, hingga P1 pernah

Invokavit Putri Mbarasi Wau, Program Studi Psikologi Universitas Kristen Satya Wacana. Email: ivnvokavitputriwau@gmail.com

Rudangta Arianti, Program Studi Psikologi Universitas Kristen Satya Wacana. Email: rudangta.sembiring@uksw.edu 


\section{GAMBARAN SUBJECTIVE WELL BEING PADA ANAK YANG MEMILIKI ORANG TUA PENYANDANG TUNA NETRA SEJAK LAHIR}

dipanggil oleh guru bimbingan konseling karena seringnya tidak mengerjakan tugas.

Sedangkan P2 sudah tidak bersekolah lagi semenjak kelas 2 SMP karena dikeluarkan dari sekolah, P2 sempat memiliki keinginan untuk mengambil paket namun dikarenakan lokasinya sangat jauh dari rumah P2 memutuskan untuk tidak lanjut sekolah.

"Saya dulu pernah ambil paket juga, tapi nggak sempat juga karena nggak ada kendaraan sekolah paket itu jauh jadi kita mikir berapa lagi itu." -P2

P2 saat ini fokus bekerja dan membantu memenuhi kebutuhan keluarga. P2 tidak memilih-milih pekerjaan asalkan itu baik dan mampu dikerjakan. P2 merasa beryukur sudah memiliki pekerjaan tetap dan pekerjaan sampingan walaupun tidak selalu ada. P2 masih memiliki keinginan dalam bekerja seperti ingin membuka usaha sendiri yaitu bengkel.

Kedua partisipan juga memiliki pandangan terhadap masa depan, apa yang harus dilakukan di kemudian hari. P1 yang saat ini duduk di bangku SMK jurusan arsitek memiliki keinginan kedepan mendalami musik di perkuliahan, namun sebelum kuliah P1 memiliki keinginan untuk bekerja terlebih dahulu hingga dapat membiayai kebutuhan pribadi, P1 tidak memiliki keinginan untuk melanjutkan jurusan arsitek karena merasa jika bekerja sesuai hobi akan membuat partisipan merasa nyaman bekerja.
"Kalau untuk kuliah mungkin

cari uang dulu buat sendiri trus

baru kuliah, kak. Kuliahnya

terakhir mungkin."-P1

"Yaa mungkin kalau kerja

sesuai hobi bakal senang gitu,

trus jalaninnya juga ngak ribet

kak."-P1

Untuk P2 yang saat ini sudah dalam dunia pekerjaan, P2 memiliki keinginan untuk terus dapat bekerja, memperoleh pekerjaan yang baik agar dapat mencukupi kebutuhan sendiri maupun membantu keluarga dalam perekonomian. Keinginan P2 dalam pekerjaan juga ingin memiliki usaha bengkel sendiri. Walaupun ayah P2 sudah bekerja, namun masih belum cukup untuk memenuhi kebutuhan keluarga, tanggungan adik yang sebentar lagi memasuki pendidikan SD memerlukan biaya yang lebih. P2 juga tidak memiliki keinginan untuk mengharapkan orang lain tetapi mau berusaha sendiri seperti bisa membuka bengkel sendiri.

"Masa depan sih ada sih kak, kita kan dah besar juga, kita nggak usah mengharapin kiri kanan lah harus kita yang beri, jangan sampai tangan dibawah ehh mending kita tangan diatas ditimbang dibawah, ya gitu kali kak." -P2 “... bisa buka bengkel sendiri atau apa dari pada disuruh-

Invokavit Putri Mbarasi Wau, Program Studi Psikologi Universitas Kristen Satya Wacana. Email: ivnvokavitputriwau@gmail.com

Rudangta Arianti, Program Studi Psikologi Universitas Kristen Satya Wacana. Email: rudangta.sembiring@uksw.edu 


\section{GAMBARAN SUBJECTIVE WELL BEING PADA ANAK YANG MEMILIKI ORANG TUA PENYANDANG TUNA NETRA SEJAK LAHIR}

suruh orang mending buka

sendiri tapi karena pandemik

belum."-P2

\section{Afek Positif}

Afek positif yang dialami oleh anak yang memiliki orang tua penyandang tunanetra adalah rasa senang, bangga dan kasih sayang. Ada beberapa hal yang membuat senang diantaranya partisipan senang masih memiliki kedua orang tua, keadaan fisik ayah bukan penghambat anak untuk berinteraksi dengan lingkungan, selain keluarga masih ada teman yang ada baik dalam keadaan suka maupun duka. P1 dan P2 sudah menerima keadaan ayah dengan keterbatasan fisik sejak kecil, P1 dan P2 sudah ditanamkan nilai-nilai positif oleh orang tua bahwa bagaimanapun harus menerima keadaan ayah dan tidak perlu merasa malu.

Partisipan sangat bangga dengan orang tua walaupun ayah memiliki keterbatasan fisik. Bangga dengan ayah masih bisa bekerja memenuhi kebutuhan keluarga dan memiliki pekerjaan tetap. Bangga ketika teman-teman memuji kemampuan ayah yang bisa bermain musik dan menjalankan mesin penggiling beras walaupun tidak dapat melihat. P1 bangga kepada keluarga yang bisa meluangkan waktu untuk bersama-sama seperti berdoa dan makan bersama.

Dalam keluarga, kedua partisipan merasa memperoleh kasih sayang dari orang tua, dibuktikan dengan orang tua peduli dan masih mencukupi kebutuhan anak. P1 yang memiliki kendala dalam studi mendapatkan sebuah dukungan dari orang tua dengan memberikan reward jika anak menyelesaikan tugas sekolah, hal ini membuat P1 kembali semangat mengerjakan tugas sekolah. Namun, jika anak juga melakukan kesalahan, orang tua tetap akan menegur dan memberikan punishment serta mengajak anak bicara agar tidak diulangin kembali.

"Ya, waktu itu sekitar dua atau tiga bulan kalo nggak salah nggak ngerjain tugas sekitar empat puluh sampai lima puluh tugas, satu minggu harus selesai baru dikasih dua ratus ribu." -P1

Sama hal nya dengan P2, P2 merasa bahwa walaupun pernah membuat orang tua kecewa karena dikeluarkan dari sekolah, namun orang tua masih peduli dalam hal menafkahi.

"Dia kalaupun bagaimana pun keadaannya dia masih peduli sama kami, itu sih memberikan yang terbaik." -

P2

\section{Afek Negatif \\ Ada beberapa pengalaman anak yang menimbulkan afek negatif, yaitu sedih dan perasaan tertekan. Afek negatif ini menjadi sesuatu yang tidak menyenangkan. Pada P1 menyadari bahwa merasa sedih pada diri sendiri}

Invokavit Putri Mbarasi Wau, Program Studi Psikologi Universitas Kristen Satya Wacana. Email: ivnvokavitputriwau@gmail.com

Rudangta Arianti, Program Studi Psikologi Universitas Kristen Satya Wacana. Email: rudangta.sembiring@uksw.edu 


\section{GAMBARAN SUBJECTIVE WELL BEING PADA ANAK YANG MEMILIKI ORANG TUA PENYANDANG TUNA NETRA SEJAK LAHIR}

karena P1 memiliki fisik normal sedangkan ayah memiliki keterbatasan fisik namun banyak hal yang dapat diperbuatnya.

"... malah saya yang merasa

sedih sama diri sendiri karena

saya banyak nggak bisa

daripada ayah."-P1

Selain perasaan sedih, P1 juga merasa tertekan dikarenakan dengan kondisi keterbatasan ayah yang tidak dapat melihat namun dahulu bisa menyelesaikan SMA, sedangkan P1 yang baru memasuki SMK sudah merasa tidak mampu menyelesaikan. Hal ini membuat P1 tertekan dengan pendidikannya bahwa ia diharuskan untuk lebih baik dari ayah.

Sedangkan P2 merasa kasihan kepada ayah karena nggak bisa melihat. Keterbatasan dalam melihat membuat ayah P2 membutuhkan orang-orang untuk menuntunya berjalan apalagi jika ditempat baru. Pengalaman sedih lain dialami P2 saat meninggalnya nenek, karena sejak bayi P2 sering dititipkan dengan nenek hingga memasuki usia sekolah, P2 merasa kehilangan. Namun dalam hal ini, partisipan tetap mampu mengatasi emosi negatif dengan rasa bersyukur masih memiliki orang tua.

\section{DISKUSI}

Hasil wawancara pada partisipan menggambarkan beberapa gambaran subjective well-being yang ditemui, gambaran pertama, kepuasan hidup anak yang memiliki orang tua penyandang tunanetra. Komponen kepuasan hidup pada domain pekerjaan, hubungan sosial, dan kesehatan, serta kepuasan hidup secara global ditemukan penelitian bahwa kebersyukuran memiliki korelasi positif terhadap subjective well-being di Amerika dan Jepang (Robustelli \& Whisman, 2018). Penelitian lain juga oleh Chan (2013) menunjukkan bahwa rasa bersyukur memiliki hubungan dengan subjective well-being. Sejalan dengan itu, kedua partisipan merasa bersyukur terhadap keluarga karena walaupun ayah sebagai tulang punggung memiliki keterbatasan fisik, namun ayah masih bisa bekerja untuk memenuhi kebutuhan keluarga, peran ayah masih berfungsi dengan baik.

Kehidupan anak mampu dipengaruhi oleh tingkat interaksi yang dilakukan oleh orang tua dan anak di dalam keluarga (Hastuti, 2008). Interaksi dapat dilihat dari kegiatan apa yang dilakukan antara orang tua dan anak di dalam keluarga (Irzalinda, dkk., 2014). Seperti halnya yang ditujukkan oleh P1, P1 menunjukkan rasa bersyukur atas kebersamaan keluarga. Kebersamaan keluarga dapat dilihat dari kegiatan doa pagi bersama dan memiliki waktu makan bersama.

Penelitian telah menunjukkan bahwa interaksi dengan keluarga dan teman juga merupakan komponen penting dari kepuasan hidup anak (Haanpää, dkk., 2019; Knies, 2017).Pada lingkungan teman sebaya maupun lingkungan dimana partisipan tinggal merasa bahwa tidak ada yang mempermasalahkan

Invokavit Putri Mbarasi Wau, Program Studi Psikologi Universitas Kristen Satya Wacana. Email: ivnvokavitputriwau@gmail.com

Rudangta Arianti, Program Studi Psikologi Universitas Kristen Satya Wacana. Email: rudangta.sembiring@uksw.edu 


\section{GAMBARAN SUBJECTIVE WELL BEING PADA ANAK YANG MEMILIKI ORANG TUA PENYANDANG TUNA NETRA SEJAK LAHIR}

keadaan fisik tunanetra pada ayah partisipan, bahkan dari kecil tidak merasa ada yang mengejek atau mengucilkan sehingga membuat kedua partispan puas terhadap lingkungan sebaya.

Papalia, Old, dan Feldman (2007) mengatakan bahwa teman sebaya merupakan sarana untuk mencapai kemandirian dan otonomi dari orang tua ditandai dengan sumber kasih sayang, pengertian, simpati, dan tuntutan moral, untuk dapat bereksperimen. P1 merasa beryukur memiliki teman yang mendukung dan menyemangati ketika memiliki masalah dalam pendidikannya. Namun, kehadiran teman juga tidak selalu membawa dampak baik, berbeda dengan P2 yang pernah dikeluarkan dari sekolah karena pergaulan buruk, sering bolos sekolah dan merokok.

Hasil penelitian yang dilakukan oleh International Survey of Children Well-Being di Nepal menunjukkan hal yang membuat sebagian besar anak merasa puas di sekolah adalah guru memperlakukan mereka dengan baik dan mereka merasa aman di sekolah karena kedisiplinan yang ditanamkan (Bhomi, 2016). Berbeda halnya dengan P1 yang merasa kurang puas dengan pendidikannya saat ini karena merasa kurang mengerti pembelajaran karena sistem daring dan memiliki guru yang galak serta ketus. Sikap guru yang ketus membuat P1 tidak semangat dalam pelajaran terlebih pelajaran yang diampuh oleh gruru tersebut. Namun disatu sisi, saat ini P1 menemukan kepuasan ketika sudah menemukan keinginan masa depannya yaitu ingin menjadi musisi dan akan lebih memiliki kepuasan jika nantinya bisa menuruti keinginan ayah untuk terus lanjut hingga kuliah. Dalam hal ini, partisipan optimis untuk mengejar apa yang diinginkan dan mendorongannya untuk meningkatkan diri agar mampu meraih cita-cita. Penelitian oleh Hutz, dkk., (2014) mengatakan bahwa optimisme dan harapan memengaruhi subjective well-being yang mampu memungkinkan untuk mencapai keberhasilan. Sedangkan P2 yang sudah fokus bekerja memiliki kepuasan ketika mendapat pengalaman bekerja dan bisa membelikan sesuatu yang diinginakan atau dibutuhkan keluarga. Sebuah penelitian menyebutkan bahwa anak yang bekerja untuk mendapatkan uang atau mengatasi kemiskinan akan merasa bangga dengan apa yang mereka peroleh dari bekerja dan merasa dirinya berarti (Aufseser, dkk., 2016).

Gambaran kedua yaitu kemampuan menyadari pengalaman afek positif, yang muncul dalam bentuk emosi menyenangkan. Kedua partisipan merasa senang masih memiliki kedua orang tua, keadaan fisik ayah bukan penghambat anak untuk berinteraksi dengan lingkungan, senang selain keluarga masih ada teman-teman yang selalu ada baik suka maupun duka. Hasil dari penelitian yang dilakukan, menemukan faktor yang paling penting bagi perkembangan remaja adalah hubungan sosial yang meliputi keluarga, teman, guru dan orang dewasa yang lainnya (Cunsolo, 2017). Kedua partisipan sangat

Invokavit Putri Mbarasi Wau, Program Studi Psikologi Universitas Kristen Satya Wacana. Email: ivnvokavitputriwau@gmail.com

Rudangta Arianti, Program Studi Psikologi Universitas Kristen Satya Wacana. Email: rudangta.sembiring@uksw.edu 


\section{GAMBARAN SUBJECTIVE WELL BEING PADA ANAK YANG MEMILIKI ORANG TUA PENYANDANG TUNA NETRA SEJAK LAHIR}

bangga dengan orang tua walaupun ayah memiliki keterbatasan fisik. Bangga dengan ayah masih bisa bekerja memenuhi kebutuhan keluarga, memiliki pekerjaan tetap. Bangga ketika teman-teman memuji kemampuan ayah yang bisa bermain musik dan menjalankan mesin penggiling beras walaupun tidak dapat melihat. P1 bangga kepada keluarga yang bisa meluangkan waktu untuk bersama-sama seperti berdoa dan makan bersama.

Bagi anak, keluarga merupakan sumber utama untuk mendapatkan kasih sayang, perlindungan, dan identitas (Lestari, 2012). Kedua partisipan merasa mendapatkan kasih sayang dari orang tua, dibuktikan dengan orang tua peduli dan masih mencukupi kebutuhan anak. Kasih sayang dibuktikan dengan P1 yang memiliki kendala dalam studi mendapatkan sebuah dukungan dari orang tua dengan memberikan reward jika anak menyelesaikan tugas sekolah, hal ini membuat P1 kembali semangat mengerjakan tugas sekolah. Namun, jika anak juga melakukan kesalahan, orang tua tetap akan menegur dan memberikan punishment serta mengajak anak bicara agar tidak diulangin kembali. Metode yang digunakan orang tua untuk memberikan motivasi kepada anak yaitu dengan reward and punishment. Kompri (2016) mengatakan reward yaitu hadiah, penghargaan, atau imbalan, sedangkan punishment yaitu suatu hukuman atau sanksi yang biasanya dilakukan ketika apa yang menjadi target tertentu tidak tercapai, atau ada perilaku yang tidak sesuai dengan norma.

Begitu juga dengan P2 yang merasa dalam keluarga memiliki rasa saling menghargai, tidak egois dan merasa masih dipedulikan oleh ayah. Hubungan postitif yang terjalin antara anak dan orang tua dapat menandakan bahwa tingginya subjective well-being dan rendahnya distress individu (Mudjiran, Niken Hartati, 2017). P2 juga tidak merasa keberatan dan senang membantu jika Ayah butuh bantuan.

Gambaran ketiga yaitu kemampuan menyadari afek negatif, yang muncul dalam bentuk emosi tidak menyenangkan. Pada P1 menyadari bahwa merasa sedih pada diri sendiri karena P1 memiliki fisik normal sedangkan ayah memiliki keterbatasan fisik, namun banyak hal yang dapat diperbuatnya. Hal tersebut membuat self esteem pada anak merasa rendah, seperti pada penelitian Li, Lan dan Ju (2015) yang mengatakan bahwa subjective well-being memiliki pengaruh yang signifikan terhadap self esteem individu.

Sedangkan P2 merasa kasihan kepada ayah karena tidak bisa melihat. Keterbatasan dalam melihat membuat ayah P2 membutuhkan orang-orang untuk menuntunya berjalan apalagi jika di tempat baru. Pengalaman sedih lain dialami P2 saat meninggalnya nenek, karena sejak bayi P2 sering dititipkan dengan nenek hingga memasuki usia sekolah, P2 merasa kehilangan. Namun dalam hal ini, partisipan tetap

Invokavit Putri Mbarasi Wau, Program Studi Psikologi Universitas Kristen Satya Wacana. Email: ivnvokavitputriwau@gmail.com

Rudangta Arianti, Program Studi Psikologi Universitas Kristen Satya Wacana. Email: rudangta.sembiring@uksw.edu 
mampu mengatasi emosi negatif dengan rasa

bersyukur masih memiliki orang tua.

\section{Gambar 1}

Subjective well-being pada anak yang memiliki orang tua penyandang tunanetra.

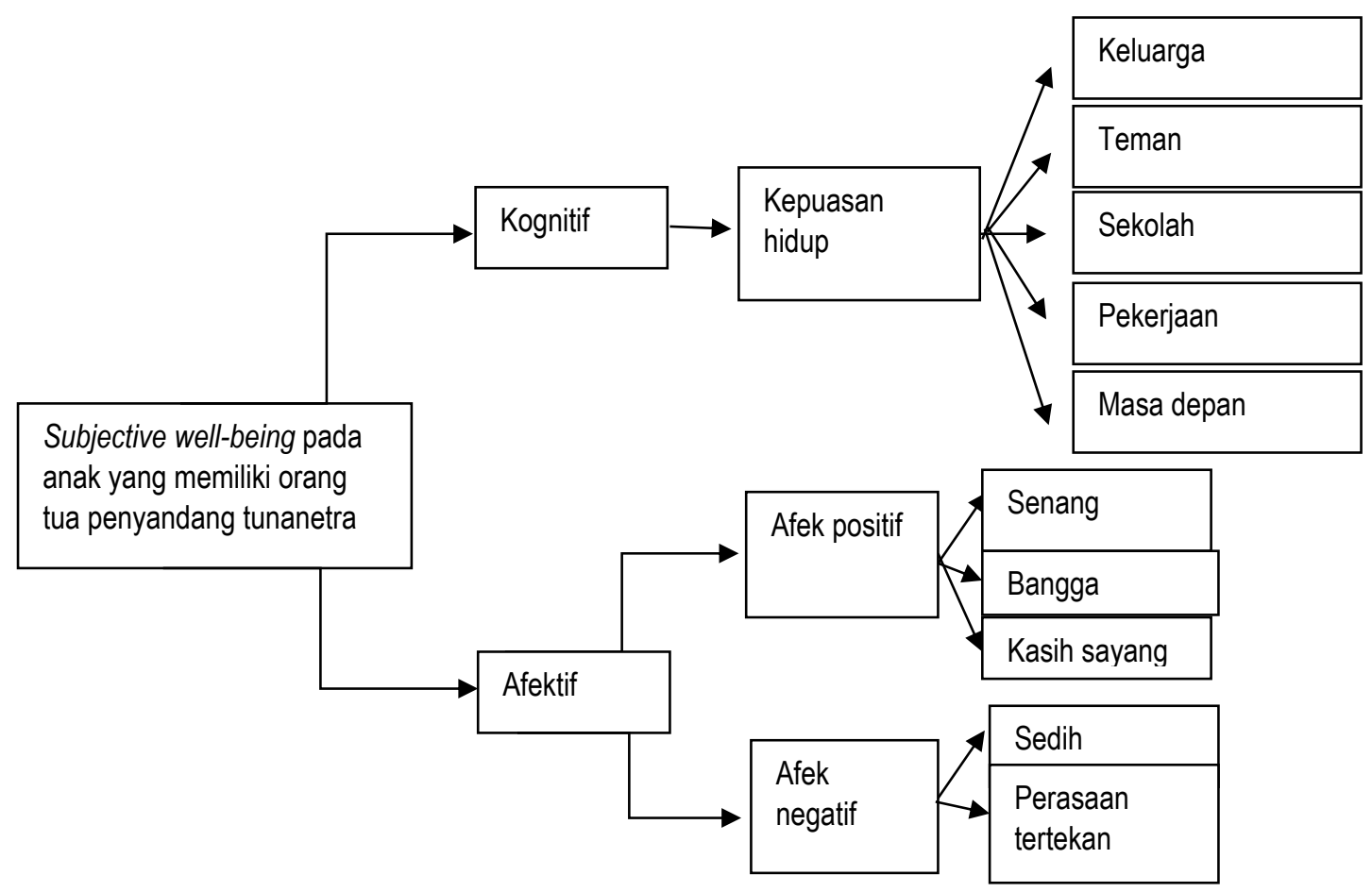

\section{SIMPULAN DAN SARAN}

Dari hasil penelitian yang telah dilakukan, diperoleh bahwa kondisi fisik orang tua mampu memengaruhi subjective well-being pada anak. Kedua partisipan memiliki subjective wellbeing tinggi yang ditandai dengan memiliki afek positif yang lebih dominan dibandingkan dengan afek negatif serta memilki kepuasan hidup walaupun memiliki orang tua penyandang tunanetra. Afek positif lebih dominan dibandingkan afek negatif seperti partisipan bersyukur masih memiliki orang tua, teman- teman yang tidak mempermasalahkan kondisi orang tua, dan keterbatasan fisik orang tua tidak menghambat masa depan anak. Sementara, afek negatif yaitu perasaan sedih dan tertekan karena anak harus lebih mampu dan berhasil dari orang tua penyandang tunanetra. Ditemukan juga bahwa terdapat faktor-faktor lain yang mampu memengaruhi subjective well-being di antaranya dari peran orang tua yang telah menanamkan nilai-nilai positif pada anak sejak dini untuk menerima keadaan fisik ayah sehingga anak sudah menerima keadaan fisik ayah, rasa

Invokavit Putri Mbarasi Wau, Program Studi Psikologi Universitas Kristen Satya Wacana. Email: ivnvokavitputriwau@gmail.com

Rudangta Arianti, Program Studi Psikologi Universitas Kristen Satya Wacana. Email: rudangta.sembiring@uksw.edu 
bersyukur anak yang masih memiliki keluarga terutama ayah yang masih mampu menafkahi keluarga dan lingkungan sosial yang menerima anak dengan keadaan orang tua penyandang tunanetra.

Dalam penelitian ini, tentunya terdapat beberapa kekurangan serta keterbatasan seperti tidak dapat berinteraksi dan mengobservasi secara langsung kepada partisipan dikarenakan pademi covid-19 yang mengharuskan jaga jarak. Walau demikian, penelitian ini sudah berusaha untuk menggali dari pertanyaan wawancara yang diajukan. Untuk penelitian selanjutnya diharapkan dapat membahas dan membandingkan subjective well-being dengan penyandang disabilitas lainnya.

\section{DAFTAR PUSTAKA}

Amato, P. R. (2005). The impact of family formation change on the cognitive, social, and emotional well-being of the next generation. Future of Children. Diunduh dari:

https://www.coursehero.com/file/11225803 lamato-2005/ tanggal 22 Oktober 2020.

Aufseeser, D., Bourdillon, M., Carothers, R.,\& Lecoufle, O. (2018). Children's work and children's well-being: implications for policy. Development Policy Review, 36(2), 241-261.

https://doi.org/10.1111/dpr.12215.

Bhomi, A. L. (2016). Nepal. Children's views on their lives and well-being in, 17, 43-46.

chan, D. W. (2013). Subjective well-being of Hong Kong Chinese teachers: The contribution of gratitude, forgiveness, and the orientations to happiness. Teaching and Teacher Education, 32, 22-30.

Chen, W. W. (2014). The relationship between perceived parenting style, filial piety, and life satisfaction in Hong Kong. Journal of Family https://doi.org/10.1037/a0036819.

Creswell, J. W. (2014). Research design: qualitative, quantitative and mixed methods approaches (4th ed.). Thousand Oaks, CA: Sage.

Creswell, J. W. (2016). Research design: Pendekatan metode kualitatif. kuantitatif, dan campuran (4th ed). Yogyakarta: Pustaka Pelajar.

Cunsolo, S. (2017). Subjective wellbeing during adolescence: a literature review on key factors relating to adolescent's subjective wellbeing and education outcomes. Studi Sulla Formazione, 20(1), 81-94. https://doi.org/10.13128/Studi.

Diener, E. and C. S. (2003). Subjective WellBeing Is Desirable, But Not the Summum Bonum. Interdisciplinary Workshop on Well-Being.

Diener, E., Oishi, S., \& Lucas, R. E. (2002). Subjective well-being: The science of happiness and life satisfaction. Dalam C.R. Snyder \& S.J. Lopez (Ed.). Oxford Handbook of Positive Psychology, 2, 6373.

Diener, E. (2009). The Science of Well-Being: The Collected Works of Ed Diener. New York: Springer Science. https://doi.org/10.1007/978-90-481-2350$\underline{6}$.

Diener, E., \& Suh, E. M. (1997). Measuring quality of life: Economic, social, and subjective indicators. Social Indicators Research, 40(1), 189-216. https://doi.org/10.1023/a:1006859511756.

Invokavit Putri Mbarasi Wau, Program Studi Psikologi Universitas Kristen Satya Wacana. Email: ivnvokavitputriwau@gmail.com

Rudangta Arianti, Program Studi Psikologi Universitas Kristen Satya Wacana. Email: rudangta.sembiring@uksw.edu 
Diener, E., Suh, E. M., Lucas, R. E., \& Smith, H. L. (1999). Subjective well-being: Three decades of progress. Psychological Bulletin, 125(2), 276-302.. https://doi.org/10.1037/00332909.125.2.276.

Haanpää, L., Kuula, M., \& Hakovirta, M. (2019). Social relationships, child poverty, and children's life satisfaction. Social Sciences, $8(2)$.

https://doi.org/10.3390/socsci8020035.

Hastuti, D. (2008). Pengasuhan: Teori, prinsip dan aplikasinya. Bogor: Departemen IImu Keluarga dan Konsumen, Fakultas Ekologi Manusia, Institut Pertanian Bogor.

Hurlock, E. (1997). Psikologi perkembangan suatu pendekatan sepanjang rentang kehidupan. Jakarta: Penerbit Erlangga.

Hutz, C. S., Midgett, A., Pacico, J. C., Bastianello, M. R., \& Zanon, C. (2014). The relationship of hope, optimism, personality in Brazilians and Americans. Psychology, 5(6), 514522.

https://doi.org/10.4236/psych.2014.56061.

Irzalinda, V., Herien, P., \& Istiqlaliyah, M. (2014). Aktivitas bersama orang tua-anak dan perlindungan anak meningkatkan kesejahteraan subjektif anak. Jurnal IImu Keluarga Dan Konsumen, 7(1), 40-47. https://doi.org/10.24156/jikk.2014.7.1.40.

Kasim, E. R., Fransiska, A., Lusli, M., \& Okta, S. (2010). Analisis situasi penyandang disabilitas di Indonesia: Sebuah deskreview. Pusat Kajian Disabilitas, Fakultas IImu-IImu Sosial dan Politik Universitas Indonesia.

Knies, G. (2017). Income effects on children's life satisfaction: Longitudinal evidence for England. 2017-02. http://hdl.handle.net/10419/163545.

kompri. (2016). Motivasi pembelajaran perspektif guru dan siswa. Bandung: PT Remaja Rosdakarya Offset.
Lam, W. W. T., Fielding, R., McDowell, I., Johnston, J., Chan, S., Leung, G. M., \& Lam, T. H. (2012). Perspectives on family health, happiness and harmony $(3 \mathrm{H})$ among Hong Kong Chinese people: A qualitative study Health Education Research, 27(5), 767-779. https://doi.org/10.1093/her/cys087.

Lestari, S. (2012). Psikologi keluarga: penanaman nilai dan penanganan konflik dalam keluarga. Jakarta: Kencana.

Li, Y., Lan, J., \& Ju, C. (2015). Self-esteem, gender, and the relationship between extraversion and subjective wellbeing. Social Behavior and Personality: An International Journal, 43(8), 12431254. https://doi.org/10.2224/sbp.2015.43. $\underline{8.1243 .}$

Meggiolaro, S., \& Ongaro, F. (2014). Family contexts and adolescents' emotional status. Journal of Youth Studies, 17(10), 1306-1329.

https://doi.org/10.1080/13676261.2014.91 8246.

Mudjiran, M., Hartati, N., \& Rinaldi, R. (2018). Optimalisasi pengasuhan pada keluarga miskin dalam rangka meningkatkan kesejahteraan subyektif anak di kota Padang. Jurnal RAP (Riset Aktual Psikologi Universitas Negeri Padang), 8(2), 158-169.

Pavot, W., \& Diener, E. (1993). Review of the satisfaction with life scale psychological assessment. Psychological Assessment, 5(2), 164-172).

Robustelli, B. L., \& Whisman, M. A. (2018). Gratitude and life satisfaction in the United States and Japan. Journal of Happiness Studies: An Interdisciplinary Forum on Subjective Well-Being, 19(1), 4155. https://doi.org/10.1007/s10902-0169802-5.

Rothman, J. (2018). Social work practice across disability (Ed. 2). New York: Routledge. http://dx.doi.org/10.4324/9781315178028-

Invokavit Putri Mbarasi Wau, Program Studi Psikologi Universitas Kristen Satya Wacana. Email: ivnvokavitputriwau@gmail.com

Rudangta Arianti, Program Studi Psikologi Universitas Kristen Satya Wacana. Email: rudangta.sembiring@uksw.edu 
GAMBARAN SUBJECTIVE WELL BEING PADA ANAK YANG MEMILIKI ORANG TUA PENYANDANG TUNA NETRA SEJAK LAHIR

15.

Sari, C. P., \& Coralia, F. (2015). Subjective wellbeing pada istri yang memiliki pasangan tunanetra. Seminar psikologi \& kemanusiaan, Bandung: Universitas Islam Bandung.

Schinazi, V. R. (2007). Psychosocial implications of blindness and low-vision. Diunduh dari https://www.researchgate.net/publication/3 2887600_Psychosocial_implications_ofbli ndness and low-vision.

Strózik, D., Strózik, T., \& Szwarc, K. (2016). The subjective well-being of school children. The first findings from the children's worlds study in Poland. Springer. Child Indicators
Research, $\quad 9, \quad 39-50$. https://doi.org/10.1007/s12187-015-9312$\underline{8}$.

Suldo, S. M., \& Fefer, S. A. (2013). Parent-child relationships and well-being. Research, Applications, and Interventions for Children and Adolescents (Pp. 131-147). Diakses dari Spinger, Dordrecht. https://doi.org/10.1007/978-94-007-63982__.Prenadamedia Group.

Suldo, S. M., \& Fefer, S. A. (2013). Parent-child relationships and well-being. In Research, applications, and interventions for children and adolescents (pp. 131-147). Springer, Dordrecht.

Invokavit Putri Mbarasi Wau, Program Studi Psikologi Universitas Kristen Satya Wacana. Email: ivnvokavitputriwau@gmail.com

Rudangta Arianti, Program Studi Psikologi Universitas Kristen Satya Wacana. Email: rudangta.sembiring@uksw.edu 